\title{
History and Politics and the Politics of History: Poland and Its Museums of Contemporary History
}

\author{
${ }^{1}$ Amerika-Institut, University of Munich (LMU), Munich, Germany, E-mail: etges@Imu.de \\ ${ }^{2}$ Centre for Contemporary History, Potsdam, Cermany, E-mail: zuendorf@zzf-potsdam.de \\ ${ }^{3}$ Institute of Political Studies of the Polish Academy of Sciences, Warsaw, Poland, E-mail: pmach@isppan.home.pl
}

\begin{abstract}
:
The Polish museum landscape has turned into a battleground between politicians and historians. Much of that has focused on the highly praised Museum of the Second World War in Gdańsk which opened in March 2017. Its founding director Pawel Machcewicz was dismissed when the conservative-nationalist party "Law and Justice" came to power. The article and the interview with Machcewicz discuss that story, the founding and exhibition design of other Polish history museums as well as the politics of history in Poland and beyond.
\end{abstract}

Keywords: museums, Second World War, Poland, public history, politics of history

DOI: 10.1515/iph-2018-0006

\section{Irmgard Zündorf and Andreas Etges, Introduction}

During the Cold War cultures of remembrance differed significantly between Eastern and Western Europe. The revolutions of 1989-1991 did not change this situation, rather it seems as if the divide between the memory cultures has grown even bigger. These differences become most obvious with regard to the celebration of remembrance days, the introduction of new "history-laws" or the founding of museums, memorials or monuments in Eastern European and Eastern Central European countries.

Particularly distinct is this development in the field of museums, especially regarding Germany's neighbor Poland. Since Poland became a sovereign country in 1989 and a member of the European Union in 2004, it seems more museums for contemporary history were established by the national and/or local governments there than in any other European country during this time. The most prominent examples include the Warsaw Rising Museum (2004), the former Enamel Factory of Oskar Schindler (2010) in Kraków; the European Solidarity Centre in Gdańsk (2014), the Polin Museum of the History of Polish Jews in Warsaw (2013/14), the Emigration Museum in Gdynia (2015), the Ulma Family Museum of Poles Saving Jews in Markova (2016), the Centrum Historii Zajezdnia (Historical Centre Depot) in Wroclaw (2016), the Museum Dialogue Centre Upheavals in Szczecin (2016) and, of course, the highly disputed Museum of the Second World War in Gdańsk (2017). These museums exhibit different aspects of Polish history, but are mainly focused on the Second World War II and Cold War topics. Even more museums are planned by the current government, such as a Museum of Polish History or a Museum of Cursed Soldiers and Political Prisoners of the Polish People's Republic - both in the country's capital Warsaw.

However, the peculiarity of the Polish case is not only based on the number of new museums, but also on the approach of these museums, which represent specific types of "narrative scenographic museums": The exhibitions deliver carefully selected messages, are composed of installations and offer options for possible interactions with the visitors. ${ }^{1}$ The museums seem to be "mediums for popularizing history rather than [...] collections of historical artefacts," as the historians Piotr M. Majewski and Rafał Wnuk wrote. ${ }^{2}$ They identified a new museum trend in Poland "based on an immersive museum concept [...] which tries to influence the visitor using a number of different stimuli." ${ }^{3}$ These stimuli can be found in a specific scenography, in a certain type of lightning, in using special colors, and special materials. They are also spurred by the sound effects used in the exhibitions and, last but not least, even by the smell of some exhibition parts. The new Polish museums make use of a huge spectrum of multimedia installations. Utilizing these stimuli, the museums aim at triggering much more emotions than the "'sterile' museums that present only artifacts and their descriptions," as for example most German museums do. ${ }^{4}$

Andreas Etges is the corresponding author.

(c) 2018 Walter de Gruyter $\mathrm{CmbH}$, Berlin/Boston.

This content is free. 
This new type of museum is very popular in Poland: In 2015, the museums counted 30 million visitors - a very high number taking into account that the whole country has about 38 million inhabitants. Many visitors are international tourists, but the main audience targeted by founders of the new museums are the Polish people.

Since the museums have been to a large degree accepted by the Polish society, Polish politicians started to look at them as very useful tools to spread their own messages. When the conservative-nationalist party "Law and Justice" (PiS) won the absolute majority in the Polish parliamentary election in 2015, this became particularly relevant, because the new government "has shifted its attention to the politics of memory," as the historian Florian Peters pointed out. ${ }^{5}$ This is why some of the new museums are not only supported by the government but are also influenced by the politicians. Thus, the Polish museum landscape has turned into a battleground between politicians and historians. ${ }^{6}$ Public interest in the highly politicized debates about the instrumentalization of history for political purposes, however, seems to be rather low in Poland. In Western Europe, on the contrary, they attract a broad audience.

From a public history point of view, the newly found attention is a curse and a blessing at the same time, as the "battle" about the Museum of the Second World War in Gdańsk shows. ${ }^{7}$ The museum is also financed by the Polish government. It opened its doors to visitors in March 2017. Shortly after the opening, the director of the Museum, Paweł Machcewicz, was forced to leave his position and a new director was installed. Since the dismissal of Machcewicz, the new head of the museum has tried to change the permanent exhibition to make it more congruent with the PiS view of Polish history. We wanted to know what these changes mean not only for the Museum of the Second World War but also for all public museums in Poland.

Therefore we spoke with the former director Paweł Machcewicz, a Polish historian, museum expert and one of the most prominent "fighters" in the Polish museum "battle."

How do you explain the "Polish museum boom"? Are the Polish people more interested in historical museums than for example Germans or Italians?

I think that we should start by saying that history really matters in Poland. It sometimes matters too much. The Polish people are interested in history, but politicians also got very much interested in history. The turning point was the opening of the Warsaw Rising Museum in 2004. Lech Kaczynski, the Law and Justice politician who created this museum was elected Polish president in 2005. So the creation of this museum was a sort of recipe how to achieve a political success. That partially explains why in a country not as rich as Germany there were always funds to create new museums, so called state national museums, founded by the national government, but also many municipal museums. Mayors of major cities hoped that new monuments and museums would be seen as a political success and thereby would increase their chances to win the next election. And on the other hand, the opening of the Warsaw Rising Museum in 2004 was a success because of the public attention and the popularity it gained, with more than half a million visitors each year. Museums became crucial instruments of offering Poles contact with history and they would not necessarily look for historical explanations in the books written by historians, or even in films or television series.

But why museums and not just a historical film - for example? These museums are very expensive - not just the founding/building - but also the following annual support.

I think that has something to do with the way people want to spend their time. Museums became the place where you go with your whole family, with your kids, and also with the expectation that museums should be entertaining. The Museum of the Warsaw Rising is also a place where all elementary and high school students go on trips.

Who is the expected audience? Mostly Poles or rather foreign visitors?

It depends on each case. In Kraków there is a very interesting museum created in the former "Schindler factory" about the war and occupation in Kraków. More than half of the visitors come from foreign countries, many from the United States and Israel, to a great extent due to the success of the movie 'Schindlers List.' It is one of the best Polish museums, but is not so popular among Poles. In the memorial site in Betżec the great majority of visitors are Jewish groups. The former German Nazi extermination camp is located on the periphery of Poland and not many Poles come. There are such museums as the Museum of the Warsaw Rising and the Museum of the Second World War visited by both Poles and foreigners. In the case of Gdansk, we always planned to make this museum in a way universal. Poles would come to visit, but we also wanted to use this museum to explain Polish history to foreigners. When curating the exhibit our team was concerned about some explanations being too complicated, and we always asked whether a Portuguese tourist would understand it. Why a tourist from Portugal? Because this is an opposite anchor of the European continent and I bet that $90 \%$ of the Portuguese tourists have no idea about Polish history and also, Portugal didn't take part in the Second World War. We wanted to create a whole narrative absolutely understandable to the Portuguese tourists. And I think it does work for international visitors.

Which messages do the museums and the Polish government want to spread?

It depends on the government. The Law and Justice Party does have a clear historical message, a so-called politics of history. Former governments and other parties usually did not pay so much attention to history and did not attempt to exploit it so conspicuously.

Than let us speak about a specific case, the Museum of the Second World War: What was the goal of the government in funding it, and what was your aim as the founding director of the Museum? 
The Museum of the Second World War was founded by the Civic Platform government, a liberal government. The starting point was an article that I published in 2007, arguing that Poland should create a museum of the Second World War. I gave two reasons: first, Poland had joined the European Union in 2004 and the integration proceeded smoothly in terms of the economy, law, and the political system. At least at that moment we believed in it. But the historical memories of two parts of the continent are different. And the goal of this museum was to introduce the Polish and Eastern European wartime experience into the main of narratives about the war which have been dominated by a western approach. The war experiences of Poland and of the Eastern part of Europe was to a great extent different from the experiences in Western Europe. For example, the German occupation was much more brutal in Poland than in Denmark or in France. Poland in 1939 experienced not only German but also Soviet aggression and occupation. The end of the war meant something completely different to Western Europe for which it was just the liberation, the beginning of the rebuilding, democracy, later on the beginning of European integration. For Poland it meant the end of the German occupation, but it also meant the beginning of a new enslavement by the Soviet Union. And I argued that all these unique features of the Polish and Eastern European experience should be included in the museum of the Second World War.

The second reason was the Polish-German context at that time. There were very acute controversies regarding the efforts to create a new museum in Berlin to commemorate the suffering of the German expellees from Poland and elsewhere after the end of the war. I argued that instead of protesting against this German idea and trying to reject it, we in Poland should create a much larger museum which would present the overall story of the war.

The new prime minister of Poland, Donald Tusk, got interested in this idea. I think that he needed some new opening in the Polish-German relations. He wanted to remove historical controversies from the political agenda and let historians and museums deal with them. Tusk offered me the possibility to create the museum, but he never got involved in any details. I had complete freedom, complete independence who I wanted to work with, who I wanted on the advisory board, what would be the content of the museum. The museum was created by historians, curators and designers. Politicians only gave the money and, in the case of Tusk, they gave us some protection from any external interference. But this model is quite unique. And I think it will not be repeated in Poland. Another model - this is the approach Jarosław Kaczyński and other Law and Justice politicians - is to treat history as a sort of a political tool which can be exploited. And they have quite clear visions what it should look like. Nowadays historians involved in creating exhibitions don't have the freedom and independence I had. Museums which have been initiated by this new government are subordinated to this "overall scheme" how to understand, how to interpret, how to represent Polish history.

The Museum of the Second World War has been highly praised internationally. Nevertheless you were fired soon after its opening, and a new government changed the structure of the museum and installed a new director. Could you explain this?

Immediately after we had published our concept paper in the fall of 2008, we were attacked by the right wing in Poland. Jarosław Kaczyński, then the leader of the Law and Justice party in opposition, and other right-wing politicians and journalists attacked this concept as an attempt by Polish and European liberal leaders to destroy Polish national identity. They criticized the idea that we wanted to present not only Polish experience but also the experience of other nations. It was vehemently rejected as jeopardizing Polish uniqueness or as minimizing Polish sufferings and Polish heroism. This has been the main line of attacks against our museum, that it wanted to present the experience of other nations alongside the Polish experience, attacks which thereby completely reject any sort of international analysis. The other thing that was completely rejected was our focus on the fate of civilians. From the very beginning we had declared that this should not be a predominantly military museum. World War II was different from previous wars in the way it affected civilians. In Poland, more than 90 percent of the Polish citizens who died were not soldiers but civilians, Polish Jews and ethnic Poles. But we were accused that our aim was to diminish the heroism of the Polish soldiers and that we wanted to create a pacifistic museum, an anti-war museum, which presented the war as a great tragedy by focusing on the sufferings of people. In the last two years some new elements were added: that we did not devote enough attention to the Polish Catholic church and that we should have presented more about the Poles saving Jews. The whole controversy became completely irrational. Last summer Jarosław Kaczyński, the most powerful man in Poland, said in a television interview that the Museum of the Second World War was not a part of the Polish politics of history but that it had been imposed upon Poland by the German politics of history and that this museum was a gift of Donald Tusk for Angela Merkel. The minister of culture said in one of his interviews that from the very beginning we acted on the orders of Berlin. It is absurd and an insult to say this about the project, which from the very beginning had the intention of showing among other things how brutal the German occupation in Poland was, and that was intended to be a response to the German initiatives focusing on the sufferings of the German civilians and the German expellees. So, if you ask me why the Polish government has organized a huge campaign against the biggest historical museum in Poland and why this government did all it could to prevent this museum from being opened and why this government even now devotes so much energy to smearing this museum and to destroy the exhibition - I cannot explain it in a rational way. It has a lot to do with the radicalization of politics and the atmosphere in Poland. It reflects an attempt to eliminate from the public sphere ideas and people regarded as enemies. But on the other hand, this is the quite logical outcome of developments which had been accumulating in Poland in the last years.

Since you left the museum a new director was appointed. Have there been other changes? 
The situation is quite paradoxical. From the very first day the mission of the new director of the biggest historical museum in Poland has been to criticize his own museum and to insult the people who created this museum and declare that he would change this museum to make it more Polish. But the exhibition has pretty much remained unchanged for more than six months after I was fired. They started to introduce changes at the end of October 2017. The most important change was removing the video and photographs from the last section of the exhibition. The original film presented wars, conflicts, and violence after the Second World War. The last scenes which were watched by visitors before leaving the museum were scenes from the war in Syria, the war in the Ukraine and also scenes of refugees trying to escape from these conflict zones. It had been criticized as pacifistic, as presenting the war as a tragedy. The new director said that after seeing this film a visitor would think that the war is a horrible thing and that violence should be avoided. But the message of the museum should be to prepare a Polish visitor to be ready to use weapons and to fight and defend his or her country. So, this is a complete clash of expectations, of historical sensitivities and also in understanding what is the role of the museum.

The original film was replaced by a four-minute cartoon animation made in the style of a computer game. The "Unconquered" was produced by the Institute of National Remembrance and is advertised as an "animated film telling the story of Poland's heroic struggle for independence 1939-1989" It is available on the web and on YouTube, but so is the original film. Before it was removed, one of the visitors managed to film it with a smartphone and put it online where 30.000 people watched it in the first few days. In a digital world, censorship cannot be complete anymore. Comparing these two films is a very unique opportunity to discuss various approaches to history.

They also removed some objects and that is also rather significant: One is a quite unique artefact from the pre-war section of the exhibition on the Soviet Union. We presented Soviet Communism, Italian Fascism and National Socialism using two overlapping dimensions. The first one was about propaganda and ideology. We tried to explain why these regimes managed to seduce millions of people and make them commit horrible crimes. The second dimension was the reality, mostly terror. To illustrate this first dimension of propaganda we put in a showcase a sort of a game, a toy game for Soviet children about the achievements of the 5-year-plan, about industrialization and collectivization of agriculture, about the fight against the Orthodox Church. And they removed this object and replaced it with a gun. There are many guns in the museum, so I think it really destroys a part of our message, but it is very significant because it reflects how the right wing perceives Communism: only through the perspective of terror and not paying attention to the ideology. The most recent change which was announced recently is adding a new element in the section devoted to Auschwitz about Poles saving Jews. The topic of Poles saving Jews has been present in the exhibition from the very beginning. But we also showed the murdering of Jews in Jedwabne. This has been criticized by the new directorship, and possibly the next move will be to change or remove the part of the exhibition discussing the Jedwabne pogrom.

Do you expect them to the change the exhibit bit by bit to fully remake the museum?

I think it cannot go that far because this is a huge and very consistent exhibition and it is not so easy to change it. It would be a huge scandal to close the museum for three months or half a year in order to thoroughly change its exhibition. They would have to use heavy equipment, bulldozers to destroy the exhibition which cost 14 million Euros and which took us eight years to complete. So, probably they will change only some isolated parts of the exhibition and add some new elements which would be completely inconsistent and spoil the whole message, because the exhibition if it wants to be convincing has to be consistent in terms of an intellectual message, in terms of language used, in terms of design. Adding some completely different or even hostile elements to the existing exhibition would simply make it chaotic.

In January myself and three other main authors of the exhibition, all historians, sued the new director, in a court in Gdansk. We attempt to defend the integrity of the exhibition on the grounds of copyright. We are not sure about the outcome, because this is an unprecedented case and courts in Poland have been under very strong political pressure. I believe that one day it will be possible to restore the exhibition to its original form because we document all the changes which have been introduced and as a historian I know very well that no regime lasts forever.

What you describe is mostly a political debate, not a historical or scholarly one.

It was mostly political, reflecting to some extent a much deeper cultural and mental polarization in Poland. We were attacked and called traitors, lackeys of Berlin and Brussels; sometimes even by right-wing historians. But I wouldn't say that it was a real debate. For example, the minister of culture commissioned three reviews. Two authors of these reviews were historians very close to the Law and Justice Party, the third one was a journalist who had attacked our concept already in 2008. But these reviews were kept secret for many months. After the declassification under the freedom of information act we published them on the website of the museum and wrote a response to these reviews, and we invited the authors of these reviews to come to Gdansk and to have a public debate, but they refused. I wouldn't call these reviews a sort of a scholarly approach. The authors argued that we had created a kind of anti-war/pacifistic museum, that our exhibition could be called the exemplification of a Communist slogan: "No more war," that the Polish perspective is not represented enough, and so on.

Do you think there is a typical "exhibition language" in the new Polish museums? Is there a "Polish style" to display history compared to other museums in other countries?

In Poland, after the opening of the Warsaw Rising Museum there were very strong expectations that museums should be modern, attractive and to some extent entertaining, have a lot of multimedia, screens, but also some special effects. One of the most significant elements of this exhibition is for example the ticking heart of Warsaw. It doesn't mean something 
special because Warsaw doesn't have any actual heart as a city, I mean any physical heart. But when you enter the exhibition you can hear some sound. Many museums which were created afterwards somehow followed this example, that we should have a lot of multimedia, we should play a lot with sound, with light, with some special installations, which would recreate the atmosphere or even sometimes real places, like streets in the occupied Kraków or the room in the Gestapo headquarters which was used for interrogating Poles. Such a re-enactment was installed in one of the museums in Kraków. In fact, these newly created museums often neglect objects. It was believed that objects are not necessary to have a first-class exhibition. And actually, this approach was followed not only by the right-wing which created the Warsaw Rising Museum, but was followed as well by the people who created the Museum of the History of Polish Jews. They admit themselves that at the time when they started to work on the exhibition there was the widespread fascination with new technologies. If you go to the Polin Museum you will find very few original objects. There are around 160 objects in such a huge museum and there is a lot of multimedia. When we started to create the museum in Gdańsk our deliberate decision was to do it differently. We focused to a great extent on original objects and created a collection from scratch. When I left the museum, we had more than 40000 original objects and we included around 2000 objects in the permanent exhibition. Sometimes these objects are the key element of the narrative. To illustrate the narrative we to a great extent focused upon objects. But we also included multimedia and scenographic installations which recreate some historical realities, taking into account the dominant expectations of the Polish public.

Are Polish museums more emotional, e. g. in contrast to German museums?

I think it would be a good assessment. I remember that a few years ago I invited a group of German historians, German museum experts and directors of German museums to Gdansk, and we presented them some plans of the exhibitions and elements of its design. And basically, they said that they liked the concept very much, but they asked: 'Why is this so emotional? Why is it so baroque, in a way of re-enactments, staging some elements?'

If you go to the exhibition of the Museum of the Second World War you enter into some places where designers on purpose wanted to create the feeling of danger or suffering. There is a very emotional part of the exhibition devoted to the fate of Soviet prisoners of war. We show horrible photographs or films of skeletons, corpses of thousands of Soviet prisoners of war, who died of hunger in the German camps and we use quite touching orthodox church music, which commemorates the dead. And the design is very sinister, it is a rather small room with concrete walls. The overall feeling is of danger, threat, horrible tragedy and this is conveyed not only through the information or photographs, but also through the feeling of closeness, the music and it was criticized as an exaggeration by Germans historians and museum experts. But on the other hand, this design was prepared by a design company from Brussels and this team was very international and consisted of designers from Belgium and from France. There was also an Israeli historian in it.

There is quite an interesting comparison with the American and Russian museums of World War II which would probably fulfil the desires of our current Law and Justice government to have a purely Polish oriented and predominantly military museum. The Museum of the Great Patriotic War in Moscow conveys a very one-dimensional message about Soviet sacrifices and Soviet heroism. The National WWII Museum in New Orleans to some extent is the reverse side of the museum in Moscow because it focuses almost exclusively on the military and American experiences of the war. One major part is about American soldiers fighting in Europe and another one about those who fought in the Pacific. According to my count, Poland was mentioned two times, the Soviet Union three times. One was the presentation of Joseph Stalin and another one was the presentation of a Harley Davidson motorcycle of which the Soviet Union had received 150.000 under the lend-lease agreement from the United States.

A few months ago a new law was passed in Poland, the so-called "Holocaust bill." Everyone who says publicly that the Polish nation bears any responsibility for the "German" crimes against humanity could be sentenced to imprisonment. How does the new law interfere with academic freedom but also the public discourse, and furthermore, does it have any consequences for public history in Poland and abroad?

In theory research and art are exempted from this law. But in case of dissemination of the results of the research they are not exempt. So a historian can publish a book and he or she should not be concerned about the legal ramifications but if he or she gives an interview to a newspaper or if he or she publishes an article presenting his or her results of the research in mass circulation newspaper, they could be prosecuted. Recently under the pressure of the Israeli government the possibility of criminal prosecution was removed from the law but one could be still sued on the grounds of the civil law and face severe financial consequences. As a historian and as Polish citizen I am strongly opposed to that. I think that only hate language should be prosecuted but not opinions about history. Representatives of Poland's ruling party admitted that this law could be used against Jan Tomasz Gross, the author of "Neighbors", 8 book which revealed the Jedwabne massacre. The law could intimidate historians, especially young historians, to avoid sensitive issues in their research. It also harmed Poland's international reputation. The way Polish historians had confronted the country's difficult past had gained Poland a lot of respect abroad. And now, this law which intends to defend the so-called good image of Polish history is absolutely devastating for the Polish state and for us as Polish historians. We do not know what will happen in the future. This international outcry somehow made the government think about this law, but the law is still pending; it has not been used yet against anyone but one day it might. 
There is a new discussion about the victims of the Second World War: Who were they? Poles, Jews or both? Should there be a special memorial for the murdered Poles in Berlin, next to the Memorial to the Murdered Jews of Europe?

I'm in favor of this idea, also because first of all Poles were victims. The German genocide, the Nazi genocide started in 1939 in Poland. The first "Einsatzgruppen" were created before the aggression against Poland. And these death squads operated in Poland, they executed Poles who had been put on an elimination list. This is not widely known, the extremely brutal German politics against Poles was somehow overlooked. It was in the shadow of the Holocaust, but also in the shadow of the crimes committed in the Soviet Union. The famous exhibition about the crimes of the German Wehrmacht started its narrative in 1941 with the attack on the Soviet Union and the war in the Balkans. It completely omitted the German crimes and also the crimes of the Wehrmacht committed in Poland. So I think that for the sake of creating really good relations between Germans and the Poles such a monument would be a great gesture towards the Poles. And also because the right-wing in Poland exploits the concerns that the Germans do not pay any attention to the sufferings of the Poles, the crimes committed by Germans against the Poles.

But we should not now get involved in any sort of a competition of the victims. The fate of the Jews was exceptional because all the Jews were meant to be killed by the Nazis. But on the other hand, the genocide committed upon the Polish nation happened on such a massive scale and is not recognized in Germany sufficiently.

There is a discussion in Germany about how many memorials we have for the victims of the Holocaust and the victims of the Soviet occupation or the crimes committed by the East German government. Is there a comparable discussion in Poland?

After the collapse of the communism in 1989 there was a widespread feeling that there was no knowledge, no recognition in Western Europe regarding communist crimes. And the efforts of many Polish governments and other public institutions aimed at conveying this story about Soviet aggression, about the Soviet terror against the Poles and against East Europe. To some extent it was successful. The European Parliament adopted some resolutions which gave recognition to the victims of the communist regimes. There is a new commemoration day, August 23, which is about remembering the Hitler-Stalin Pact. For a long time I believed that this process was proceeding, but in last two years I think that we still have the disruption and many nations want to look back mostly at their own historical experience and are not so interested in the experience of other nations.

There is another idea in Poland for a so called "Polocaust-Museum" to remember the Polish victims of the Stalinist great terror. There also is the suggestion to create a Museum for the Polish Saviors of Jews.

I think that this term "polocaust" was invented by an advisor to Jarosław Kaczyński and it was supposed to be the museum not only of the Stalinist victims but also of Poles who were victims of the Nazi terror. This idea reflects a strategic orientation that we should focus exclusively on the sufferings of the Polish people and on the heroism of the Polish people and that there is no place for a more complicated history, no place for a critical, analytical approach. That could also be seen in the criticism of our museum exhibit. But this would mean to create a propaganda museum with a crude message, would eliminate the more complicated issues, the grey zones which usually constitute a great part of the historical reality, and would also eliminate the history of Jedwabne.

Both, governments and people in Eastern Europe seem to be very interested in history, especially contemporary history. Is this perception correct and if it is, how do you explain this interest? Or is it a Polish peculiarity?

I think that what we have experienced is not a Polish peculiarity, but is part of a much broader international phenomenon of rejecting an international approach to history. The attacks against our museum, against our exhibition were deeply anti-European. They reflect a deeply isolationist and very nationalist orientation, that is even xenophobic. We see a similar politics in Hungary and to some extent in Austria. There is the right wing party "Alternative für Deutschland" in Germany, the "Front National" in France, there is Donald Trump. So while Poland might be a very prominent example, it is a part of a broader phenomenon. In my view this is partly a rejection of globalization and a search for national roots, national identity.

How can we fight this populist tendency?

I don't have any good recipe. I can only give you my own experience. I think that one should be stubborn and consistent in one's views and actions. So, on the one hand, I lost, because I was removed from my position and the exhibition of the museum is being changed now. But on the other hand I have a feeling of a great victory. I managed to open the museum to the public against all the countermeasures of my government. This controversy became one of the most public issues in Poland and I think it was a story which made many people, who are not so much interested in history, to think about it. More than 300000 people visited the museum in the first six month after it opened. There were long lines of people trying to get tickets, either in Gdansk in front of the museum building or online. So however it ends, it already had a great impact upon what people think about history and I think we managed to create an alternative approach to history, an alternative to this prevalent approach promoted by the government. And I think that Poland really will be a little bit different after this huge controversy. It was one of the top public issues presented in the newspapers, in the news on the television. This shows that it really matters what you say as a historian, what you write and what exhibitions you create. Sometimes there are situations where you simply have to do your job whatever the results will be and whatever consequences you will face. 


\section{Acknowledgements}

The editors would like to thank Bartosz Makowski for his permission to publish his photographs.

\section{Appendix}
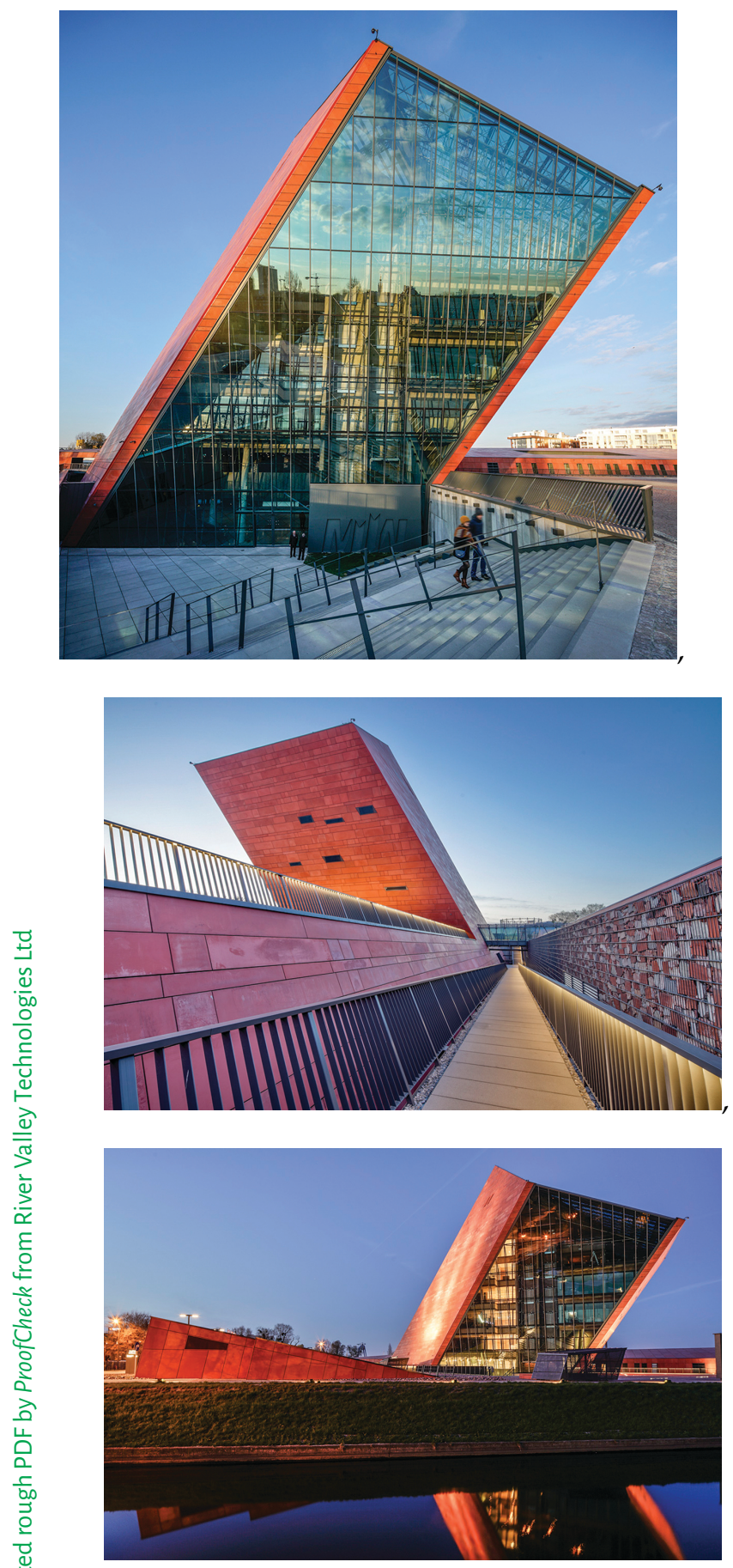

Fot. Bartosz Makowski - www.makowski.co

The building of the Museum of the Second World War in Gdańsk. The permanent exhibition is located underground and has got a size of approx. 6000 square meters. 


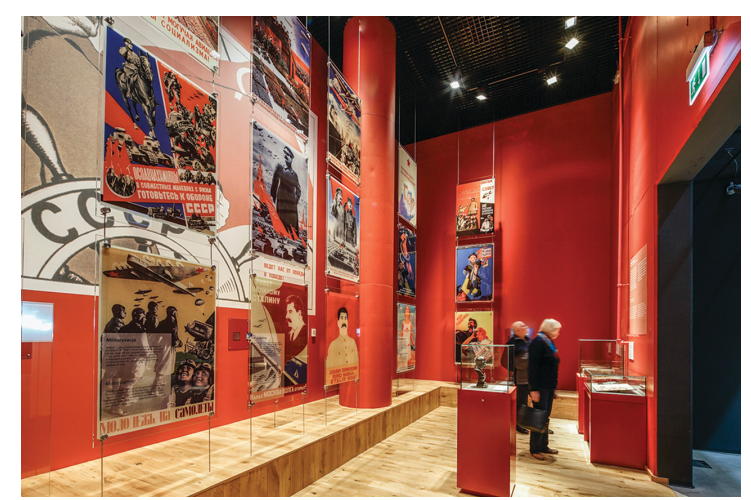

Fot. Bartosz Makowski - www.makowski.co

The section of the permanent exhibition presenting Soviet communism. One of the artifacts from this section has already been removed: a board game for Soviet children from the 1930s. It was an example of the Soviet propaganda about the successes of the five-year plan, collectivization of the agriculture and the fight against the Orthodox church. It was replaced by a gun which is a good indication of a different understanding of the totalitarian regimes.

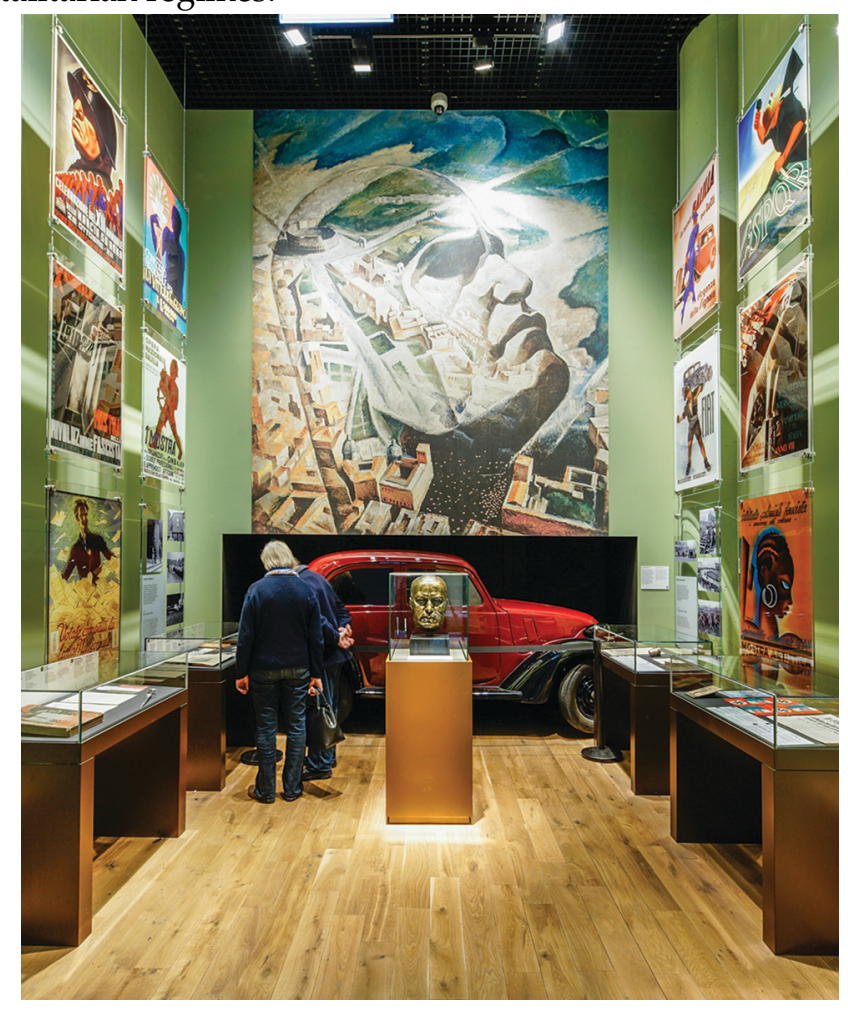

Fot. Bartosz Makowski - www.makowski.co

The section about Italian Fascism. 


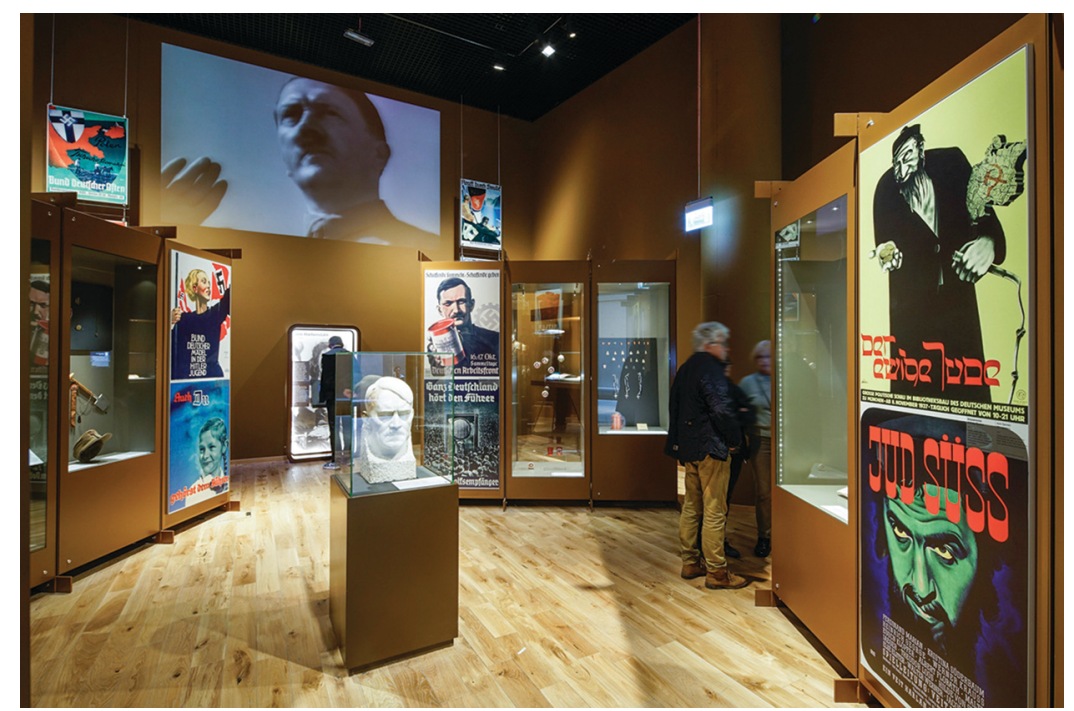

Fot. Bartosz Makowski - www.makowski.co

The section about National Socialism. The sculpture of Hitler's head was made by Josef Thorak and was undug in a backyard of the National Museum in Gdańsk in 2014. Presumably it was hidden there by Germans before the fall of Danzig in March 1945.

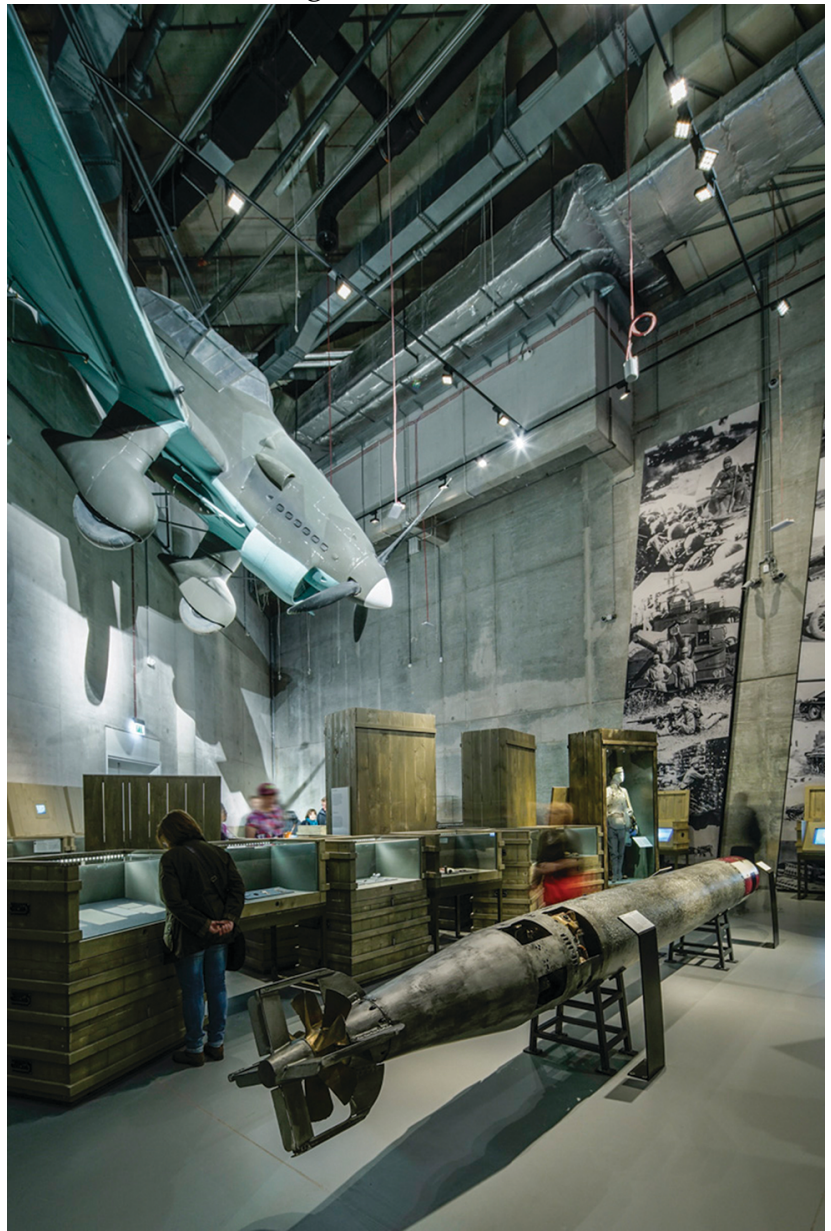

Fot. Bartosz Makowski - www.makowski.co

The section about the military campaigns, evolution of military technique and everyday life of soldiers. 


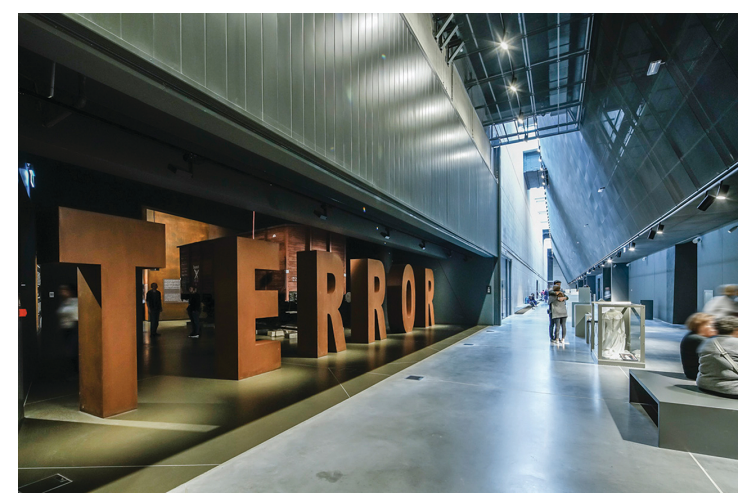

Fot. Bartosz Makowski - www.makowski.co

The entrance to the section devoted to various forms of Nazi and Soviet terror.

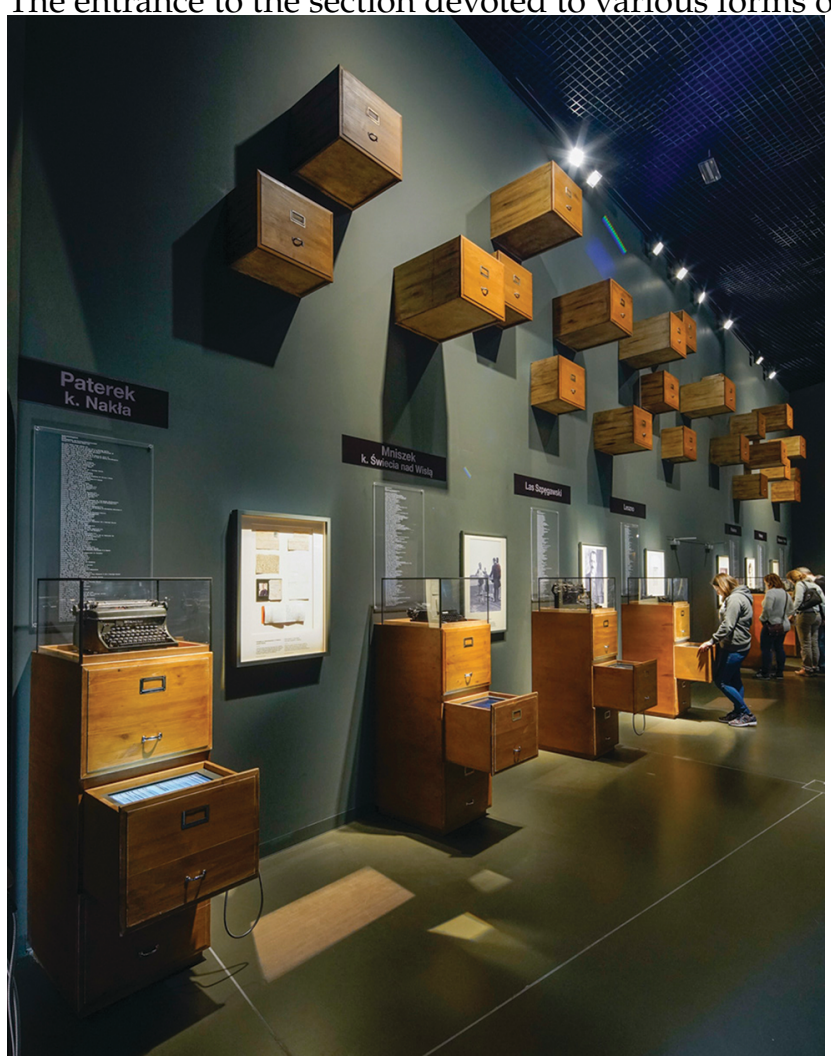

Fot. Bartosz Makowski - www.makowski.co

The section about German terror against Poles in 1939. Its design evokes the planned, "bureaucratic" character of the German repression which aimed at eliminating Polish elites. 


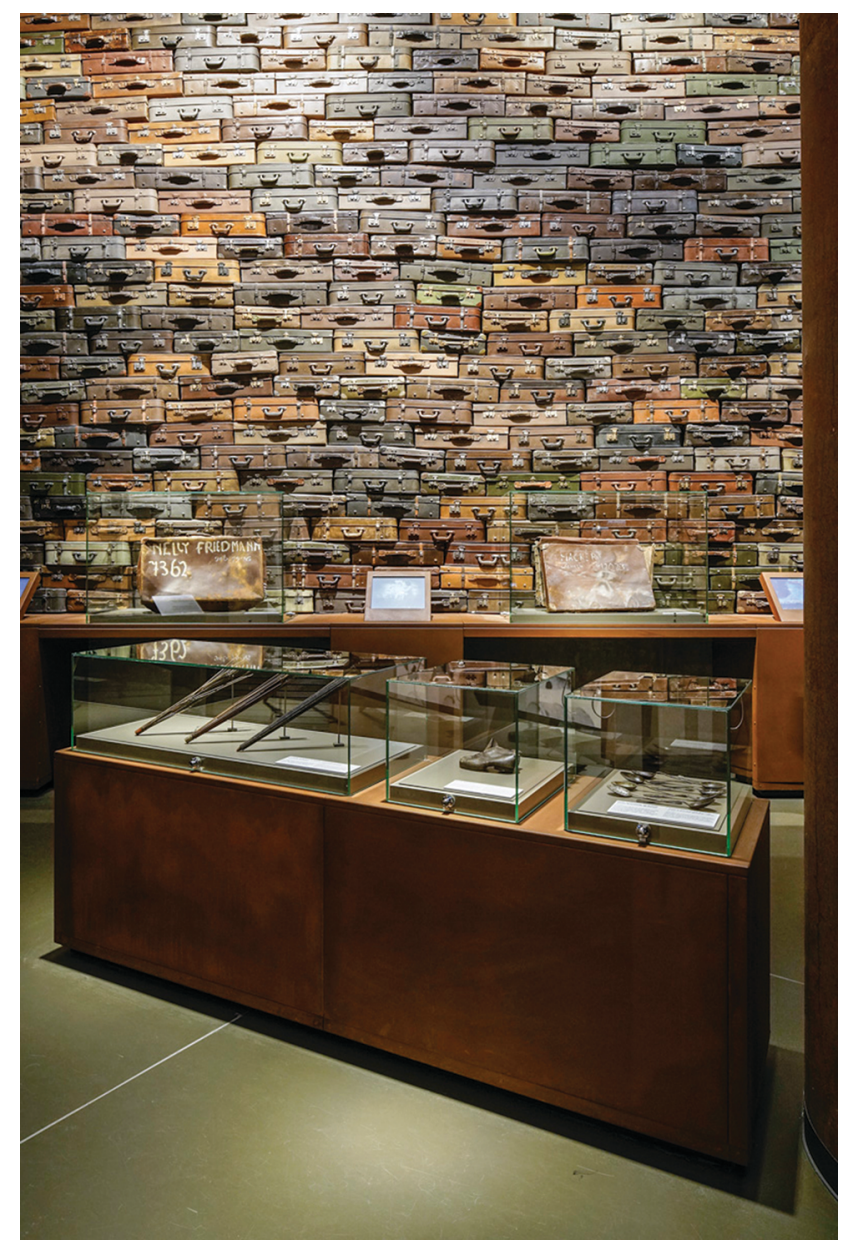

Fot. Bartosz Makowski - www.makowski.co

The room devoted to the extermination of Jews in Auschwitz, part of the section presenting the Holocaust.

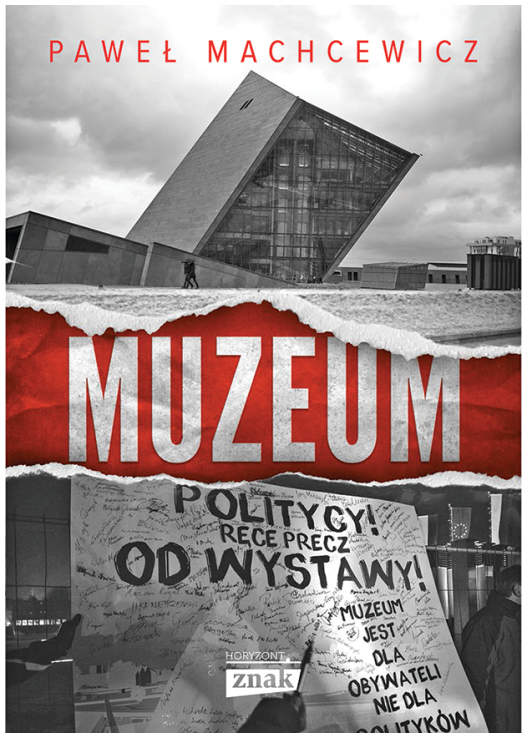

\section{Notes}

1 Michał Niezabitowski, “Der erste Kongress der polnischen Museumsfachleute und die Transformation der polnischen Museumslandschaft," Historie. Jahrbuch des Zentrums für Historische Forschung Berlin der Polnischen Akademie der Wissenschaften 10 (2016): 21-32, here 28.

2 Piotr M. Majewski and Rafał Wnuk, "Between Heroisation and Martyrology. The Second World War in Selected Museums in Central and Eastern Europe," The Polish Review 60 (2015) 4: 3-30, here 4.

3 Majewski/Wnuk, "Heroisation and Martyrology," 26.

4 ibid., 27. 
5 Florian Peters, “Remaking Polish National History: Reenactment over Reflection," Cultures of History Forum (03.10.2016), URL: http:/ / www.culture-of-history.uni-jena.de//politics/poland/remaking-polish-national-history-reenactment-over-reflection/.
6 Eva
Hoffmann,
"Hearing
Poland's
Ghosts,"
The New
York
Review
of Books
65
(2018)

(1)

7 Andrzej Hoja, "An Engaged Narrative: the Permanent Exhibition of the Museum of the Second World War in Gdańsk, "Cultures of History Forum (24.07.2017), URL: http://www.culture-of-history.uni-jena.de//exhibitions/poland/an-engaged-narrative-the-permanentexhibition-of-the-museum-of-the-second-world-war-in-gdansk/.

8 Jan Tomasz Gross: Neighbors. The Destruction of the Jewish Community in Jedwabne, Poland (Princeton: Princeton University Press 2001).

\section{Bionotes}

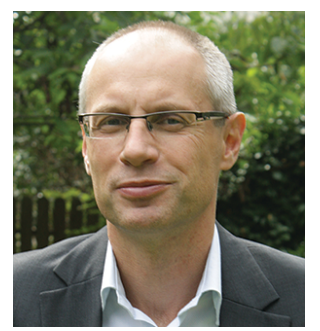

Prof. Dr. Paweł Machcewicz Historian, professor at the Institute of Political Studies of the Polish Academy of Sciences; 2008-2017 - founding director of the Museum of the Second World War in Gdańsk; he has taught at the Warsaw University and the Nicolaus Copernicus University in Torun and was a co-founder of the Institute of National Remembrance, in 2000-2006 was director of its research and education branch. His many books include Rebellious Satellite: Poland 1956 (2009) and Poland's War on Radio Free Europe, 1950-1989 (2014) in the Cold War Series of the Woodrow Wilson Center Press and Stanford University Press. He was also editor and co-author of the two-volume series Wokót Jedwabnego (Jedwabne and Beyond, 2002; in German: Der Beginn der Vernichtung. Zum Mord an den Juden in Jedwabne und Umgebung in Sommer 1941. Neue Forschungsergebnisse polnischer Historiker, Fibre, Osnabrück 2004). He also published about politics of history and memory conflicts in Poland and East Central Europe after 1989: Spory o historię 2000-2011 (Historical Battles 2000-2011), 2012. His most recent book describes the history of creating the Museum of the Second World in Gdańsk and controversies it evoked ("Muzeum", Kraków 2017, ZNAK). Its German edition was published in May 2018: Der umkämpfte Krieg. Das Museum des Zweiten Weltkriegs in Danzig. Entstehung und Streit (Harrassowitz Verlag)

portrait photo by Anna Machcewicz 